\title{
Proxy agents, auxiliary forces, and sovereign defection: assessing the outcomes of using non-state actors incivil conflicts
}

\author{
Rauta Vladimir a, * \\ aportsmouth Business School @ Cranwell, Whittle Hall, RAF College, Sleaford, UK \\ Email: Vladimir.Rauta@port.ac.uk
}

\begin{abstract}
This article interrogates the role of non-state armedactors inthe Ukrainiancivilconflict. Theaim of this articleis twofold. First, itseeks to identify the differences between the patterns of military intervention in Crimea (direct, covert intervention), and those in the South-East (mixed direct and indirect-proxy-intervention). Itdoessoby assessingtheextentofRussiantroopinvolvementandthatofexternalsponsorshiptonon-state actors. Second, itputsforward a tentativetheoreticalframeworkthatallowsdistinguishingbetweenthedifferentoutcomes the two patterns of interventiongenerate. Here, thefocusisontherole ofnon-stateactorsinthetwointerventionistscenarios. Thecoreargumentisthattheuseof non-state actorsis aimedat sovereigndefection. Thearticleintroduces the conceptof sovereigndefectionanddefinesitas abreak-away from an existing state. To capture the differences between the outcomes of the interventions in Crimea and South-East, sovereign defection is classified into two categories: inward and outward. Outward sovereign defection is equated to the territorial seizure of the Crimean Peninsula by Russian Special Forces, aided by existing criminalgangs actinginan auxiliarycapacity. Inward sovereigndefection refers to the external sponsorship ofthe secessionistrebelsinSouth-EastUkraineandtheiruseas proxyforceswiththepurpose of creatinga politicalbuffer-zonein theshape of a frozen conflict. Todemonstratetheseclaims, thearticleanalysestheconfigurationofthedynamicsofviolenceinbothregions. It effectivelyarguesthat, in pursuing sovereign defection, the auxiliary and proxy forces operate under two competing dynamics of violence, delegative and non-delegative, withdistinctimplicationsto the courseandfutureoftheconflict.
\end{abstract}

Keywords Proxy war proxy agent auxiliary force Ukraine sovereign defection civilwar 
Accounts of the annexation of the Crimean Peninsula to the Russian Federation in March2014 emphasized primarily its switt character (Snegovaya 2015), whilepointingtowardsthecomingofageofa shiftin Russian contemporarywarfare(Karber 2015) thathadbeenonitswaysincethe move towards what Major-General Vladimir Slipchenko called 'sixth generation of warfare' (Kipp 2012). Serhiy Kunitsayn, the ex-premier of Crimea and former Permanent Representative of the President of Ukraine to Crimea, recalls to have been the last bulwark of the legitimate Ukrainian Government thereatthetime:

IcametotheofficeoftheCrimeanunionofAfghanwarveterans, wherewedecidedtostandas a shieldbetweentheRussianandUkrainian troops, and halfan hour later the building was blocked and Aksyonov's ${ }^{1}$ bands led by the 'green men' began to storm it. (Kunitsyn 2014)

What started as protests in late November 2013 (Grytsenko and Walker 2013), and escalated into violent demonstrations over the course of the following months (Kramer and Higgins 2014), effectively turned into an internationalized civil war ${ }^{2}$ with the annexation of Crimea and the eruption of armed hostilities in the South-Eastern regions of Donetsk and Lugansk.

At the centre of the rapid escalation of violence was the involvement of Special Forces (Galeotti 2015), volunteer groups such as the far-right Azov and Donbass battalions (Reuters 2015), and paramilitary configurations such as the organizationally reformed and party-turned Right Sector (Kozlowska 2014). The national and intemational media paid great attention to the issue. While some reports raised significant questions about their actions, others focused on their origins (Lipsky 2014; Shevchenko 2014). Yet, the main interest was in the so-called 'little green men' and less in the self-defence forces accompanying them, on the rebel groups in the South-East or on the armed volunteers helping the Ukrainian army.

Moreover, intheirinvestigativepursuits, accounts ofthe developmentscollapsedunderthesamelabeldifferenttypes ofarmedgroups, or employed labels in an interchangeable fashion. 'Special Forces', 'proxy agents', 'surrogate millitas', 'state-sponsored terrorists', 'satellite groups', 'insurgents' and 'auxiliaries' became synonymous, despite referring to stand-alone entities with fundamentally different roles in the conflict.

WithPresident VladimirPutin'sadmittingthe 'littlegreenmen'inCrimeawere RussianSpecialForces (Donaldson2014), academicresearch swiftlymoved to correctingthe existingincongruities surroundingthe militaryoperations inCrimea. Karagiannismadethe case for understanding Crimea'sannexationas a resultof'acovertoperationwithSpecial ForcesandalocalPro-RussianmilliainCrimea'(2014,409). Galeottinoted that 'while claiming to be a local militia, this well-armed and highly professional unit turned out to be the first deployment of operators from the KSO (Special Operations Command)' $(2015,50)$, and Cimbalaexplained thatinstead of an overtmilitaryintervention, 'Russiaoccupied Crimea with special operationstroops, supportedbyalreadydeployedforces' (2014,359). Similarly,Hansenanalysedtheinterplayofmilitaryactionand propaganda, advancingtheidea of a 'minimalactionspace' designed 'to deter adversariesfrom investingintheconflictandto reapthebenefits of victory' $(2015,153)$. Lastly, research suchas that of Bartles and McDermottintegrated the role of the Special Forces inthe overall process of Russianmilitary modemizationand transformation(2015).

Despitethe literature coveringsignificantgroundata fastpace, keyquestionsontheoriginsandrole ofthelocal self-defenceforces, thevolunteer groups and, most importantly, the state-sponsored insurgents in the South-East remain unanswered. The puzzle concerning this article links these entities to theirfunctioninthearmed conflictand to the externalsupportthey receive. As the 'littlegreenmen' also became involvedinthearmed hostilitiesin Donetsk and Lugansk (Luhn 2014; Vlasova and Miller 2014), and as groups of armed volunteers, such as the 'men in black' (Euromaidanpress 2014) or Semen Semenchenko's Donbas battalion, reinforced the response of the Ukrainian army, paying closer attention to 
the morphology of actors involved inUkraine'sconflictsettingisimperativeforbothpolicy-makingandacademicconsiderations. Theaim ofthis articleistwofold:first, to comparatively evaluatethetypes of militaryinterventionsinCrimeaand theSouth-East, and, second, to providea theoreticalframeworkthatallowsdistinguishing betweentheoutcomesoftheeventsinCrimeaandthoseinSouth-EasternUkrainebylookingat theroleofthenon-statearmedgroups. Indoingso, the article engages in the wider ongoing debate on the changes in Russian warfare (Johnson 2015; Thornton 2015) which has emphasized the emergence of atypeof 'hybridwarfare' (Brun2010; Rojankiand Kofman2015; Sinovetsand Renz2015) and haveputforwardtheidea of the developmentofa novel 'full-spectrum conflict' (Jonssonand Seely 2015).

To this end, after assessing the intervention patterns, the article develops a tentative theoretical framework that might help with ordering the variation inempiricalobservations on the violence in Crimeaversus that inSouth-EastUkraine, and with providing a more integratedaccountofconcurring explanations of the situation. Atthe centre of the article is the claim thatthe use of non-state armedactors for the projection of politicalviolence in Ukraine is aimed at sovereign defection. The article introduces the concept of sovereign defection as a novel analytical tool for assessing the outcomes of usingnon-statearmedactors inbothinterventionistscenarios. Itis definedhereas abreak-away from anexistingstate. To capture the difference between the purpose of the application of violence in Crimea and that in the South-East, sovereign defection is classified into two categories: inward and outward. The latter refers to a physical, territorialbreakaway, the formerto a political, ideologicalone. Outward sovereigndefectionequates to the territorial seizure and annexation of the Crimean Peninsula by Russian Special Forces, aided by existing criminal gangs. Inward sovereign defection refers to theexternalsponsorshipofthesecessionistrebelsinSouth-EastUkrainewiththepurpose ofcreating a politicalbuffer-zoneintheshape of a frozen conflict. To demonstrate theseclaims, the articleanalyses the dynamics ofviolenceinboth regions. It effectivelyargues that in pursuingsovereign defection, the use of non-state armed actors frames two competing dynamics of violence, which the article labels delegative and non-delegative. At the core of these concepts is the idea of delegation of the practice of violence to third parties. It originates inthe Principal-Agenttheory which has approached delegation as a transactional enterprise focused on maximizing utility and shifting responsibility on the basis of a contractual agreement. As Gilardiargues, the standard viewis that 'a principal wishesa giventask to be executed butlacks the expertise or time to perform itand therefore delegatesittoanagent, whichgetsthejobdoneinexchangeofremuneration'(2008, 29). Inthiscase, delegationis definedinrelationtoauthority: the use of the term "delegation", [...], is meantto suggestno morethana "transferof authority" (Donnelly 2007, 3); or as 'the process by whichthe principal offers a "conditionalgrantof authority"to an agentto acton theirbehalf (Bymanand Kreps 2010,3). Inconflictresearch, however, delegationhasbeenusedto refertotheempowermentofthirdpartiesasa costsavingdeviceandto indicate 'thatexternalactors playanimportantrole in shaping the insurgency and exert control over it' (Salehyan 2010, 501). Specifically, in the process of delegation, 'states (principals) will sometimes wishto retainforeignpolicyautonomyand willdecideagainstbacking insurgentgroups'(Salehyan, Gleditsch, and Cunningham2011,711), and, in doing so, 'their willingness to back such groups will depend on the costs of direct military action and the states' ability to select and monitor appropriate agents' (Salehyan, Gleditsch, and Cunningham 2011, 711). As such, the article explains the variation in the outcomes of the situations in Crimea and the South-East by differentiating between delegative and nondelegative dynamics of violence. Specifically, it argues that delegating violence to non-state actors is observed in the South-East and is linked to promoting inward sovereign defection, while operating covertly with Special Forces, aided by local criminal gangs, accounts for pursuing outward sovereign defection by following a non-delegative dynamic of violence.

Thearticle, thus, proceeds as follows. First, itbegins by providing a briefovenview of theevents. Second, itcompares thetypes of intervention patterns inCrimeaand South-EastUkraine. Againstthis background, the article introduces the notion of sovereign defectionas a more powerful explanatory tool capable of capturing the differences between the intervention strategies. Then, it interrogates the validity of the concepts of outward and inward sovereign defection by analysing the chosen dynamics of violence, delegative and non-delegative. It concludes that the Russian Federation shifted from opting for a non-delegative dynamic of violence in Crimea to a delegative one in the South-East on the basis of significant differences in the salience of each outcome. 


\section{From maidan mayhem to secessionist strife}

In March 2014, Dmitry Rogozin, Deputy Prime Minister of Russia in charge of the defence industry, visited the recently annexed Crimea and issued a brisktweet: 'Crimeaisours. Basta!' (Millsand lsachenkov2014). A couple of monthslater, thiswasfollowedby a similarcommentonthesame social media network: 'Crimea. Every stone, every square meter of this land is soaked with Russian blood. That's whyit's ours' (Rogozin 2014). The repliesaddressed Ukrainianandinternationalcondemnatoryreactions of Russia's decisionto interveneinthepeninsula(Akinyemi2014). Former PresidentofUkraine, OleksandrTurchinovspoke oftheeventsas a clear'politicalaggression'(Wilson, Foster, andGrant2014) and international leadersfollowedsuit. Notably, the EuropeanUnionHighRepresentativeCatherineAshtonissueda statementonthe developments claimingthey represent 'an unwarranted escalation of tensions' (European Union External Action Service 2014) and the United Nations Secretary General, Ban Ki-moon, expressed great concerns over the situation (BBC News 2014a). The strong rhetoric accompanied a striking course of events that unfoldedagainsta morecomplexbackground. Thebeginningis linkedto UkrainianPresidentVictorYanukovich's decision, inNovember2013, to abandon closer economic ties with the European Union in favour of those with Russia. The public reactions saw immediate demonstrations which quickly escalated into protests with record levels of violence and high numbers of fatalities (BBC News 2014b). Soon after, Yanukoych fled the capital, and this provided what Johnson called 'the starting point for transition and escalation from the years-long non-military phase of Russia's hybrid campaign against Ukraine' $(2015$, 8). Previously, ever since the signing of the Declaration of Ukrainian Independence on 24 August 1991, the Russian Federation had relied on devised narratives 'designed to link Ukraine's future with the 'common' future of other post-Soviet countries, particularly the East Slavic ones' (Bogomolov and Lytynnenko 2012). Against this background, the transition from the soft, non-military influence saw as a first step the annexation of Crimea to the Russian Federation. In the spring of 2014, 'little green men' (Kramer and Gordon 2014) - which President Vladimir Putin would later admit to be Russian soldiers (MacFarquahar 2015) - entered and took hold of the peninsula with the help of local millibas. With the Russian ParliamentapprovingPutin'srequestto useforceasto protectRussian interests, and with overwhelmingresultsinfavourofjoining Russiaina highly contested local referendum, Crimea officially became part of Russia.

Theeventswerequicklyfollowedby unrestbreakingoutinEasternandSouthernUkraine.AsCrimeawasbeinginstitutionalizedintotheRussian Federation, rebelseparatists occupiedadministrativebuildings, airports and radiostationsincitiessuchas Donetsk, Luhanskand Kharkiv. Led by AleksandrZakharchenkoandlgorPlotnitsky, therebelgroupsinitiallyvoicedclaimsforvaryingdegrees ofautonomyandindependence. With the independenceoftheDonetskPeople'sRepublicand oftheLuhanskPeople'sRepublic, theFederalStateofNovorossiyawasofficially declaredon May 22 (Babiak 2014b). To further emphasize the rebels' determination, their millitas fused under the new United Armed Forces of Novorossiya. Pro- Russiannews agency Novorossia.su called the merger a 'truly historic' moment and 'a crucial milestone' (2014). Over the course of 2014, and into the firstmonthsof2015, the fightingintensified withsignificantbattle-andnon-battle-relatedcasualties. TheOfficeforthe Coordination of Humanitarian Affairs reports that 'since the beginning of the conflictinApril2014 and 19 June2015, at least6,503 people have beendocumentedas killedand another 16,385as wounded intheconflictzoneofEasternUkraine'(2015). Included werethe298 liveslostin thecrash, on 17 July, of the Malaysia Airlines fight MH17 from Amsterdamnear the village of Grabove in rebel-held territory. Currently, attempts at regulating the violence have seen several European brokered truces and cease-fire agreements being signed, with varying degrees of success. In December 2015, the clashes continued despite theMinskAgreementhavingbeen inplace sinceFebruary, effectivelyshowinganoverall predispositiononbothsidesforcoercivemeasuresatthe expense of diplomatic efforts.

\section{Assessing patterns of intervention}


Therearesignificantdifferencesinthetype of militaryoperations carried outin CrimeaandintheSouth-East, anditisthepurpose ofthissectionto comparativelyqualifythepattersofinterventioninbothregions. Here, thestartingassumptionistwofold:ononehand, theannexationofthe Crimean Peninsulaisseento havebeenthe resultofuse of covertactioncarried outby RussianSpecial Forces withthe collaboration oflocal armed groups, identified as local self-defence militias and formed of members of established criminal gangs (Galeotti 2014a, 2014b; Losiev 2014). On the other hand, the violence in the South-East of Ukraine unfolds according to a more complicated pattern: the pro-Russian separatists engage in armed conflict against the central govemmentinKiev whilebeing externallysupported by Russia ${ }^{3}$ as wellas accompanied by Russiantroops (Sutyagin 2015). As the following paragraphs willdiscuss, ifCrimeais a clearcase of covertdirectmilitanyintervention, thearmed struggle waged by the separatistrebels requires several clarifications since current explanations shift between treating it as either direct or indirect. The existing literature has already determined the covertdirectcharacter of the events inCrimea withKaragiannis makingthe caseforunderstanding Crimea's annexationas a resultof 'a covert operation with Special Forces and a local Pro-Russian militiain Crimea' $(2014,409)$ and Cimbala (2014) and Galeotti(2015), amongothers, stressingsimilarpoints. For this reason, the section proceeds to detailatlargethesituationinthe South-East, contendingthat, infact, itis a case of a covert military intervention retaining both direct and indirect features: Russian troops and externally supported rebels. Effectively, it is a milltary intervention where 'the non-military non-linear hybrid segment is embedded within Russia's more broadly conceived and fullyintegrated conflict spectrum and relies on the leveraging or actual employment of conventional, unconventional and nuclear forces' (Johnson 2015, 10).

First, classifying the situation in the South-East as a direct Russian military intervention requires caution and increased specificity of arguments. Much of the debate centred on the presence of Russian citizens in the separatist groups (Babiak 2014a). Journalistic accounts, academic research and official statements have repeatedly claimed that Russian citizens are involved in the fighting. For example, one of the leaders in Donetsk, Alexande Zakharchenko, was quoted in early 2014 that '3-4000 Russian citizens had joined the fight alongside the insurgents' (BBC News 2014b). This, however, erroneously adds to the argument and complicates matters significantly. As Robert Heinsch argued, 'the questions this raises are whether the Russian soldiers were following orders from their superiors when joining the rebels or were leaving the regular Russian forces during their "free time"' $(2015,330)$. Formulated under the label 'citizen', accusations of direct military intervention fail to build a strong case because, rather than being an issue of intervention, this is a question of presence of foreign fighters inconflicts. Recently, David Malet argued that foreign fighters should be definedas 'noncitizens of conflict states who join insurgencies during civil conflict' $(2013,17)$, and that they are part of the wider issues of rebel groups recruitment and organization strategies. Thomas Hegghammer stressed similar concerns, despite operating a terminological differentiation between 'domestic' and 'foreign fighters'. Accordingly, the former refers to 'a person who perpetrates or tries to perpetrate violence in the West, whereas a 'foreign fighter' is someone who leaves or tries to leave the West to fightsomewhere else' (Hegghammer 2013, 1). What does builda convincingargument, however, is the documented evidence of the presence of Russian troops and Special Forces as servicemen on active duty, as opposed to just Russian citizens.

This underlines the fundamental citizen-soldier distinction that has allowed the Kremlin to dismiss claims of military intervention on the basis of the voluntarycharacter of the fightingimpliedbytheconcept of 'citizen'4. Significantevidence, however, has substantiated claims ofdirectcovert intervention, similar to the militaryoperations in Crimea. As Ukraine's Foreign Ministry began tweeting the hashtags \#UkraineUnderAttack and \#RussialnvadedUkraine (Ministry of Foreign Affairs of Ukraine 2014), proof of troop involvement amounted considerably. Satellite imagery and digital detective work accompanied academic research in building a strong case for understanding the reality of the battlefields as a Russian miltary intervention. Thecore oftheargumentwas therisingnumbers offatalitieson the rebelside, many of whom proved to be Russiansoldiers. Recently, investigative reporting linked the deaths of three Russian senvicemen to the violence in Donbass, despite officials claiming the soldiers 
died in operations in the North Caucasus (Stallard 2015). As evidence amounted, battle-related casualties accompanied personal testimonies (Ostrovsky 2015), the capture of Russian soldiers as war prisoners and official statements documenting the situation. In regards to the latter, Ukrainian officials detailed the situation at large (Kramer and Gordon, 2014; Kramer and Higgins, 2014), with periodic reports on the state of the violence continually referencing the Russian troop involvement (Ministry of Defence of Ukraine 2014a, 2014b).

More specifically, President Poroshenko reiterated the interventionist narrative by stating that 'Russia already cynically uses its troops in Ukraine having brutally violated the basic principles of the international law' (2015).

Independentjoumalismseconded the claimsacross alltypes of evidence, and the diversenature of the reporting was proportionalto the striking character ofthefacts. Onesuchaccountproducedageographicmapping oftheplaceoforiginsofthesoldiers. TheOpen Russiaorganization, founded by Mikhail Khodorkovsky, published the report on the dead soldiers in an infographic aimed as a response to Kremlin signing a decree classifying certain peacetime deaths of soldiers as state secrets (Luhn 2015). And, while these findings may be fraught with bias in the light of the controversial relationship between Khodorkovsky and the Russian administration, other reports soon surfaced. ${ }^{5}$ Published in October 2015, Hiding in Plain Sight, Putin's War in Ukraine, is an Atlantic Council report that exposed 'the breadth and depth of Russian militanyinvolvement in Ukraine's east' (Czuperski et al. 2015, i). It emphasized the multifaceted involvement, ranging from provision of troops, training, crossborder sanctuary, and arms and munitions. This strengthens the relevance of previous investigations such as the one by the Open Russia organization or that issued by independent think tank, Bellingcat. Addressingtheconcerns of Russianrelativesofthose servinganddying,the independentthink-tankdedicatedto the use ofopen-source information, analysedtheoriginsofartilleryattacksonUkrainianmilitarypositions. Theanalysisused GoogleEarthsatelliteimages, as wellas videosfrom social media and local media reports. The complex methodology enabled Bellingcat to determine that the attacks were launched from Russian territory (2015). While experts cautioned on the accuracy of such reports on grounds of replication issues and methodological validity (Borger and Higgins 2015), such evidenceissignificantbecause, firstly, itrespondsto emergingtrendsinresearchinfavourofusingsocialmediadata(Zeitzoff,Kelly,andLotan2015), and, secondly, because it corroborates with data and conclusions from academic research. For example, a RUSI study by Igor Sutyagin documented the presence of Russiantroopsas well as reconnaissanceandspecialoperations units. Itconcluded thattheoverallfigureof Russiantroopsoperatingin EasternUkraine 'reached approximatively 9000 by thelastweek of February 2015 and hasincreased by atleast 1500-2000 personnelsincethen' (2015). Inhis analysis, Sutyaginalsonoted that, once introduced, Russiantroops 'were moved to the rear, behindrebelformations' (2015). This observation brings the assessment of the difference in patterns of military operations to the initial point: that, unlike Crimea which saw only direct, covert military intervention, the South-East marks the application of a joint, direct-indirect intervention. The discussion on troop involvement reviewed the direct component of the interventionist strategy, but it left unanswered the question of the indirect intervention. More specifically, what needs to be determined is the provision of external support to pro-Russian rebels by Russia and its impact to the projection of rebel violence.

If the core concept for determining Russian direct milltary intervention was the soldier, in the case of indirect intervention, the role is taken by external sponsorship in the form of armstransfers, hosting and military training. Thisis of significantimportanceas determiningthe extent of support to the separatistrebelorganizationallowsacknowledgingtheoperations intheSouth-Eastas beinga proxywar. As Salehyan, Gleditsch, and Cunningham argued, 'understanding external support for rebel organizations is important for the study of international relations since it constitutes a form of interstate conflict, albeit indirect' (2011, 710). Moreover, as Andrew Mumford observed, in a proxy war 'the supplying of milltary material, such as arms, ammunitionandothermilitarytechnology, by benefactorstotheirchosen proxiesistheprimewayforbenefactorstogetothersto dothefighting for them' $(2013,78)$. 
Withtheaforementioned reports highlightingtheprevalence of arms transfers, itis importantto framethe practice as partofa menuofchoice for rebels' armsprocurementstrategiesthatisdependent'onthestage oftheconflict, thesizeandstrengthofthearmedgroups, andthestatearmed forces' (Jackson2010,131). Moreover, itshouldbenoted thatitsitsalongsideothermethodssuchas theft,smuggling, weaponscapturingor developmentof wareconomies. Bourne (2007) proposes a classification of thesearmingpatterns into 'bottom-up' and 'top-down' categories andreinforcesthe relevance of the 'conflict-complex', namely the political and economic background. Studies of armament used by the terroristlabelled rebels in Ukraine pointto its provenanceto be predominantly ofdomestic originsand onlyinpartcomplementedby ingresschannelsin theform oftransfers and illicit activities(FergusonandJenzen-Jones 2014). Theoverall preponderance of domestic weaponsinUkraine is explained, infact, as anendogenous process to the conflict. This results, first, from the precarious state of the Ukrainian army and its suboptimal control over its resources (Beckhusen 2014; Lombardi 2001; Parchomenko 2002; Recknagel 2014; Sanders 2008). Marsh underlined that 'the most important factor in determining the availability of weapons to insurgents is the ability of state forces to defend their arms stockpiles' (2007, 61). Since the Ukrainian Army 'has been increasingly left by thestate to reform itselfand to surviveonitsown' (Parchomenko 2002, 284), lack of controlchallengedits ability to defend stockpiles. Second, stockpile leakages are linked to successive army defections (Shuster 2014a) that saw armed personnel switch loyalties. Since the outbreak of hostilities, this has become a common feature of the fighting even within the ranks of specialized forces, such as the riot police Berkut. ${ }^{6}$.

These processes reinforce the existing literature claiming that 'under certain circumstances domestic procurement of weapons is widespread, and is often more decisive than international transfers' (Jackson 2010, 131). The role of transfers should not, however, be misrepresented in comparison to in-country procurement methods, for its implications are politically and militarily significant. In the case of the latter, arms transfers can enhance the tactical performance of the armed groups because of the potentially high quality of provided arms. In the case of the former, it becomes a key asset to detemining cross-borderinterferenceas itplaysa constitutiveroleintheprocess ofexternalsupport. ${ }^{7}$. Specifically, as FergusonandJenzes-Jones argued, 'alien'weapons become 'flagitemsthatcanserveas significantindicators of externalsupply' $(2014,18)$. Thus, as previouslymentioned, external sponsorship is understood as strategically relevant because it adds the indirect component to the characterization of the intervention in South- EastUkraine. Specifically, by providingassistance, thesupporting-stateopensthefrontlinesofa proxy warthatcomplementsthetraditional, covert mode of direct intervention. In this way, the chosen proxy becomes 'conduit for weapons, training and funding' (Mumford 2013, 11) from benefactor wishing to influence the strategic outcome of the conflict.

In the Ukrainian scenario, the benefactor is Russia and its use of the rebels as proxies targets the Government in Kiev. While the issue remains contentious in the light of Russian denials, support in the form of arms transfers has been extensively documented. First, specialist studies concluded that the rebels are in possession of arms previously known to have been exclusively in the use of the Russian army. This is the case, for example, of the mmheavymachinegunKord, enteredinservicein1998andvirtuallyunobtainablewithoutRussianconsent(Fergusonand Jenzen-Jones 2014, 18). Second, NATO released satellite imagery reinforced claims of arms transfers. Brigadier General Nico Tak was quoted saying that large quantities of advanced weaponshadbeendetected 'includingairdefencesystems, artillery,tanks' (NATO2014). Such statementsbecameanintegrativepart of Ukrainian official discourse statements on the conflict, and have been a source of confirmation of Russian involvement. Moreover, since the benefactor- proxyrelationshiphasbeennoted to incorporate funding, training, ammingandequipping,[aswell as] theuseofthesponsor'sterritoryas a sanctuary' (Hughes 2012, 12), external support has been corroborated with evidence of Russian training and provision of logistical support (Aljazeera 2015). 
the South-East-, solves, however, only part of the puzzle. What remains is the question 'what explains the difference between choices of intervention strategy?'Toaddress thisissue, thesecond halfofthearticlearguesthatthevarianceinpatternsof performancecanbeassessedby integratingtherole and use of non-state armed groups - auxilianies in Crimea and proxy forces in the South East - into the Russian Federation's pursued outcomes.

\section{Sovereign defection and non-state armed groups}

Thissectionputsforwarda tentativetheoreticalframeworkthatlocates the situationinUkrainewithinthe Russianaim of externallypromoting sovereigndefection. Thisisdefinedas the deliberatepursuitof abreak-away from anexisting state-inthiscase, thestate ofUkraine. To capture the variation of the aim according to the previously identified patterns of militaryintervention, sovereign defection is classified into two categories: inward and outward. The latter refers to a physical, territorial breakaway, while the former to a political, ideological one. Outward sovereign defection equates to theterritorialseizureandannexationofthe CrimeanPeninsulaby RussianSpecial Forces, aided by existing criminalgangs. Herethegoal was 'to secure the most important Russian physical asset in Ukraine, namely the Black Sea Fleet' (International Institute for Strategic). Inward sovereign defection, on the other hand, refers to the external sponsorship of the secessionist rebels in South- East Ukraine with the purpose of creating a political buffer-zone inthe shape of a frozenconflict. This ultimatelyis directed at coercing 'thenew Ukrainian authorities into accommodating Moscow's broader interests in Ukraine' (International Institute for Strategic Studies 2014, ix).

Why sovereign defection? First, because of meta-theoretical considerations. Thinking theory thoroughly (Rosenau and Durfee 1999) requires developing and applying a cumulative approach to the enterprise of inquiry. Cumulation refers to the growth of knowledge in a certain research area. Itisa patternofthinkingthat mergesthepast, presentandfuture. The aim of the concept of sovereign defection is to rebalance the existing discussion towards a more integrative answer. Currently, the debate on the rationale behind the Russian interventions has been generated by generic 'identity-interest-ideology' explanations. Occasionally, these have distilled into considerations of nationalism, historical irredentism or geostrategy. More importantly, and with severe consequences to the overall conceptualization of the military interventions, this recently emerging commentary has run the error of treating Russian interference and involvement as mono-causal.

Notably, it has sought to harness the individual ability of a proposed explanation to frame the event. In doing so, it portrayed explanations as mutually exclusive and as running in opposite causal directions.

For example, Barbashin and Thoburn (2014) championed the nationalist dogma as a cause. Similarly, Shlapentokh (2014) called for a closer inspection of geopolitical Duginism, an emerging foreign policy discourse carved by anti-Western philosopher Alexander Dugin. Moreover, a debate betweenMcFaul, Sestanovich, andlinked the events to a diversionary explanation, reducing the situation to conditions of domestic stability. However, as Tsygankov commented 'what is lost in this explanation is an analysis of Putin's power structure, and his perception of the crisis and Russia's economic development' $(2015,296)$.

Very few analyses, thus, proceeded with a correlative mind-frame in which the 'intensity' of a factor did not outweigh another. Notably, Karagiannis observedthat'geopoliticsalonecannotexplainthenewRussianforeignpolicyinregion'(2014,415), and proposed linkingitto Russia's 'humiliation (unizhenija)' (emphasis in original 2014, 415) in the aftermath of the Cold War and its portrayal as the 'loser'-of the Cold War contest. Similarly, Allison (2015) framed explanations in a three layer model including geopolitical competition and structural power, identity and ideational 
factors, as well as the search for domestic political consolidation in Russia.

Sovereign defection breaks away from the general tendency of providing only a fractured analysis that performs suboptimally in the face of causal heterogeneity. It does so because of its ability to be a predicator of the logic behind the events from the stage of input to that of output, while keeping separate the category of desired outcome. Basically, it walks the narratives of intervention from beginning to end through the causal maze much like an analytic Ariadne's thread. How does it accomplish the task? First, sovereign defection allows framing both interventions as processes aimed at a 'lock-in' of preferred outcomes. It, thus, asks not a why-oriented question, but rather that of 'to what end?' Adopting the general concept of preferred outcomes moves the discussion beyond the previously mentioned generic answers as what is channelled is the flexibility of the response and not a specific category of responses. For example, the situation is no longer viewed just as a function of interests defined per power, butrathertheresultof weighing the salience of each interest in relation to context-dependent and context-developing aims.

Second, a focuson outcomes withinthesovereigndefectionframeworkaddresses inconsistenciesinthedebate. Specifically, itlocatesmacro and micro problems of current explanations. Macro failings are essentially issues of contextualizing the interventions. This refers to the tendency to approach the topic with a pronouneed Cold War mentality in which power and interest remind of the decades of long superpower competition. While Putin has beenknownto referencethedisintegrationoftheSovietUnionasoneofthe 'thegreatestgeopoliticaldisastersofthelastcentury' (BBC News 2005), anddespitetheUnitedStatesshiftingRussiato thetopofthesecuritythreatslists(Shalal2015), Ukraineisfarfrom beinga sufficientcause forreviving hegemonic ideological confrontations: "Russia misperceives itself as trapped in a zero-sum conflict of civilizations, leading to a situation that can best be characterisedasa coldpeace(Engle2014-2015,173). Thus, whatisobservedisnotapreoccupation withthewest, butratheraprioritzingoftheeast. AsJohnBiersackandShannonO'Learargued, 'theeventsinCrimea'sannexationinthe 'west' signala Russianshift"eastwards"' (2015,247). The establishmentof the EurasianEconomic Communityis a clear exampleas itis 'akey foreign-policy priority' (International Institutefor Strategic Studies2014, vii), and, whatis more, backs statements claimingthat 'Moscowis makinga geopoliticalcomebackinthe former Soviet space' (Karagiannis 2014, 400).

Butitisnotjustmacrodeficienciesthatundermineexplanations. Microproblemsconfusedebateinasimilarfashion. Here, thearticlereferstothe error of falling into the legitimation-goal trap, namely confusing narratives of legitimation with causal motivations. In the case of Ukraine, 'the Russian govermmentneeded to complicatethestorylineofwhoannexedwhom'(BiersackandO'Lear2015,247). Thishappenedagainstabackground in which Russian foreign policy remained essentially undefined and lacking clear direction for years. Not even the newly released miltary doctrine offered specific clues: 'the Kremlin neither issues a doctrine of nuclear pre-emption, nor explicitly named its perceived foes' (Sinovets and Renz 2015, 1).

Causal explanations, thus, morphed from carefully crafted legitimation narratives that referenced identity, history and nationalism. Crimea's symbolic significancewas fundamentaland its relevancewas builtthroughboth positiveand negativereinforcement. Ononehand, its historywas used to fire 'patriotic imagination' (Braithwaite 2014, 63). On the other, deliberate attempts were made to villy Ukrainian-ism in a search of discrediting other-ness and promoting Russian values and traditions. Allison aptly labelled such efforts 'justificatory smokescreens' $(2015,1259)$ and Hansen noted the way in whichpolicy-making constructed 'fiters by framingissuesinsucha way as to lead a particularpolicychallengeto a particularand predefined outcome' $(2015,142)$. However, these symbolic strings were aimed at accommodating Russian behaviour into the intemational legal order, and should not be automatically derived into causal determinism. 
Third, and most importantly, sovereign defection provides an overall more refined analysis. Here, the discussion departs from the meta-theoretical considerations of cumulationand macro-micro problems, and enters into a discussionon sovereigndefection's substantive advantages.

Military intervention, direct or indirect, overt or covert, targets the core of state authority:its ability to exercise exclusive control over a given territory. In practice, this ability has been coined under the concept of sovereignty. As defined by Krasner (1999), sovereignty applies to fourcategories of meaning: interdependence, domestic, Westphalianandinternationallegal. Forthepurposes ofthisanalysis, the focusisonthelatter acceptations. Tothisend, Westphalian sovereignty ascribes the functioning of the principles of territoriality and of exclusion of external actors from domestic authority (Krasner 1999, 20), andinternationallegalsovereigntyisconcerned with'establishingthestatus ofa politicalentityinthe internationalsystem'(Krasner 1999, 14). Against this background, sovereign defection becomes a tool for understanding the pursued outcomes of the Russian Federation in Ukraine.

Recently, Clem(2014) addressed the fundamental question of Ukraine's ability to legitimize its sovereignty in the present geopolitical circumstances oftheCrimeanannexationand oftheEastbeingengulfedbya separatistcivilwar. Atthecentrewastherelationshipbetweenterritoryand nationality, and Clem $(2014,229)$ concluded that the Ukrainian claims for sovereign legitimacy are based on the historical association of territory with an ethno-linguistic distinctive cultural group. Sovereign defection explains the Russian interventions by conceptualizing them into an attack on the territorial integrityanda challengetonational unitywhichgeneratea collapseofthecontrolovertheexerciseofauthority. First, theWestphalian sovereignty is underminedbecause both interventions resultinthealterationof the domesticauthorityarrangements viaterritorialbreaches: Crimeasees a total replacementofUkrainianauthorityby integrationwithinRussianauthority, and the South-Eastobserves theemergence ofa competingauthority infrastructure throughthebacking of separatistclaims. Second, the internationallegal sovereigntyiseroded as the annexation of Crimearemoves Ukraine's ability to exert exclusive representation over the region as a political entity of the intemational system. Moreover, the support for the separatist rebels pushes the developmentofa newpolitico-juridicalentityintheinternationalsystem, oneableto seekagreementsandrecognition. Thus, what emergesisastate ofdomesticanarchywhere'thestateapparatus losesauthorityrelativetononstatearmedgroups whoare abletobecomethehighest authority over their internal and external relations' (Vinci 2008, 296). In other words, when central authority is challenged, 'a microcosm of the 
international systemic replicated within the state' (David 1997, 557).

In this way, sovereign defection formalizes official statements accusing Russia of sovereign interference. Vasylenko, author of the first draft Declaration of State Sovereignty, was one of the first to claim that Russia never intended to respect Ukrainian sovereignty since 'it believed all along that Ukraine's independence is a temporary anomaly' (2014). Similarly, Poroshenko argued that the Russian aggression undermines 'social and political stability in order to destroy the state of Ukraine and seize its territory' (2015). But, sovereign defection pushes for further specificity in understanding the issue. Thus, based on the variations in patterns of militaryinterventions, itarguesthattwotypes of sovereigndefectionscanbe observed:inwardand outward. As mentioned, the latter refers to the territorial breakaway of Crimea and the former to a politicalbreakaway of theSouth-Eastintoan autonomous region acting as political buffer-zone. To interrogate the validity of the outward and inward types in the sovereign defection framework, the article proposes an assessment of the role of the non-state armed groups in both Crimea and the South East. Therefore, to distinguishbetween outward and inward sovereign defection, the article contends that Russia made use of two competing dynamics of violence: delegative and non-delegative. As the labels suggest, the difference between the dynamics references Russia's willingness to delegate the application of violence to third parties: delegative implies transferring authority over violence to a non-state actor which becomes a proxy agent, and reversely, non-delegative implies a concentration of the authorityand anaversiontoward authoritytransfers, otherthanminor interactionwithauxiliaryforces. Thelastsection of the articleassessesthe performance of the local self-defence forces in Crimea and that of the pro-Russian rebels in the South-East as part of Russia's application of delegative and non-delegative dynamics ofviolence.

\section{Inward-outward sovereign defection and non-state armed groups}

Definitions ofnon-statearmed groups differ'between internationallawyers, socialscientistsfrom differentdisciplines, and practitionersfrom international governmental and non-governmental organisations' (Krause and Milliken 2009, 203). Aware of this caveat, the article defines nonstate armed groups as non-state actors with 'capacity for systematic military action' (Vinci 2008, 299), which are 'at least in principle, autonomous from the structure and machinery of the state, and of the governmental and intergovernmental bodies above the formallysovereign state' (Josselin and Wallace 2003,3). The purpose of this section is to observe the construction of inward and outward sovereign defection as strategic outputs, or goalsoftheRussianinterventions. Acknowledgingthedifferencesintypes of militaryinterventions-covert, directinCrimea, andcovert, joint (direct-indirect) in the South-East-the premise of the argumentis the developmentoftwo competing dynamics of violenceforeachtype of intervention, effectively corresponding to the inward-outward categories of sovereign defections. The dynamics are defined as delegative and nondelegative and the differencerests intheuse of non-statearmedgroups. Specifically, as mentionedabove, delegativeimpliestransferring authorityoverviolenceto anon- stateactor, andnon-delegativeimpliesa concentration oftheauthorityandanaversiontowards authority transfers. Againsthisbackground, Crimea exhibits a non-delegative dynamic of violence where the integration of non-state armed groups is at maximumin an auxiliary capacity. The South-East, on theotherhand, makesa casefora delegativedynamicofviolencewherethe Russianbackedseparatiststakechargeoftheviolenceinaproxycapacity. Theessenceoftheargumentis, thus, inthedistinctionbetweenauxiliaryand proxyforcesandhowtheyareusedintheprocess of pursuingthespecific outcomes.

The literature on non-state armed groups had for long noted that 'non-state armed actors have been known to act clandestinely on behalf of states - orinconjunctionwiththestate'sownarmedactors, sometimesasformalorinformalcontractemployees'(Davis2009, 222). Recently, the literature movedtowarddrawinga cleardemarcationbetween actingonbehalfand acting inconjunction. Thelatterreferstoatypeof relationshipinvolving'a benefactor, who is astate or non-stateactor externalto the dynamicofanexisting conflict, and theirchosen proxies who aretheconduitforweapons, training and funding from the benefactor' (Mumford 2013,11). Basically, in a proxy relationship the proxy agent wages war against a target in the name of the benefactor. This effectively renders the proxy agent a third party in a conflict between the benefactor and the target where they intervene indirectly. Here, the distinctiveness of the proxyagentrests, thus, on its ability to carry outviolence through delegationfrom the benefactor. Thisis instark contradictionwiththetype of relationshipimpliedby acting inconjunction, inwhichcaseproxy forces are replaced withauxiliaryones. Muchlike proxyagents, theroleofauxiliariesinwarfarehasreceived littleattentionand, moreover, has beenoftenlabelledas 'unlawful'. Infact, itisonlyrecently thatthestudy of theirregularfighterhas beenbroughtbackintothecentreofwarstudies 
(Scheipers 2015). In underliningtheirdifferencesto proxy agentsitshouldbe noted thatwhilefunctionallysimilar, auxiliariesare relationally differentbecause theircontributionis collaborativeinnatureand associative in type. Specifically, auxiliaries have followed a path of working 'under and with' the military and, thus, their contribution to fighting should be seen as complementary and as a direct part of the military effort.

Collaboration with auxiliaries is underpinned by outward sovereign defection. As an outcome, it refers to the territorial breakaway of a region and its annexation to the territory of another state. Put in practice, this is the case of the events in Crimea. Secession and annexation were pursued by applyinga non-delegative dynamic of violence. In this case, the action was carried out by Russian Special Forces in a covert military intervention. The exact steps of

theprocess werealreadydiscussedatlengthwhencomparingbetweentypes of interventions. Thefocushere, however, isonthelocalselfdefence forces and their role. Auxiliaries in Crimeaplayed the political role ofjustifyingandlegitimizingthe interventionwiththeiractions being portrayedas supportive to the covertmilitaryintervention. Itwas essentiallycollaborativeandnon-military. Insupportofthisclaimis, first, thenature oftheauxiliary forces and, more precisely, their loose organizational structure. As documented, the self-defence forces were a patchwork of organized gangs descending from Crimea's embroiled network of criminality, which despite having a long-standing collaboration with Russia (Roslycky 2011), lacked the stability to efficiently make use of violence in a political dimension and not just criminal. Moreover, preference over delegative violence is corroborated withthe politico-militarysignificance of Crimeaas a hostoftheBlackSeaFleet, whichhasforlongbeen perceived 'as a projectorofRussianpower abroad' (Nilsson 2013, 1168).

Inward sovereign defection is qualitatively different from outward sovereign defection because it promotes only a political breakaway. Practically, this takes the form of supporting rebel claims for autonomy or independence. As noted previously, the haphazard development of events in the South-East confusedtheaims oftherebels, whichfoundthemselvesclaimingvarious degrees of independencefrom administrativeautonomyto secessionand annexationto Russia. Whatconstitutes the coreofinward sovereigndefectionas an outcomeis, however, the desireforthe establishmentofa buffer-zoneintheshape of afrozenconflict. Toclarify,frozenconflictsstandfor'conflictsthatwerenotformallyconcludedbya peaceagreement'(Tudoroiu 2012, 136), or thatare 'the resultof post-conflictsituations thathaveneverbeen properly resolved' (Kemp 2004,46). Specifically, the strategic advantage of developing a frozenconflictisthat, onceinplace, itmarkstheemergenceofa defactostate whichdisplaysorganizedpoliticalleadership receiving popular support in exchange for provision of governmental services (Pegg 1998). More importantly, the de facto state becomes a channel for blocking the activity of the 'host' state and, thus, limitingits domestic and international manoeuvre space.

The development of such a buffer-zone and establishment of frozen conflicts requires empowerment of local rebel forces which, in receiving support, become proxy forces. This characterization is an apt descriptor of the events in the South-East where 'there is little doubt that Russia has supplied armed, armouredvehicles, tanksandotherequipmenttotheinsurgentforces' (Heinsch2015,357). Thestrengthofinwardsovereigndefection to capture the attempts at fostering z zone of frozeninstabilityis reinforced whenlookingat the long-standing ractice in Russianforeignpolicy to bolster frozen conflicts. Applied specifically to the Russiannear-abroad and to theterritory of theformerSovietUnion, the practice of freezing conflicts'knows significantexamples:AbkhaziaandSouthOssetiainGeorgia,Nagorno-KarabakhinAzerbaijanand TransnistriainMoldova. As Roslykynoted, separatism intheseregions 'has playedakeyroleinmaintainingRussianinfluenceovertheregion'(2011,299), andwiththe conflictintheSouth-East showing gradual signs of transition to a frozen conflict, inward sovereign defection captures the potential in the ability of Russian forces to 'take control of Transdniester, Odessa, and Mariupol and create a buffer zone between Ukraine and Crimea' (Thomas 2015, 447).

\section{Conclusion}


The article argued that understanding the situation in Ukraine should take into consideration the generally complex causal setting leading to the events.

Itcontendedthatcausalityshouldnotstriveforcompletespecificationofsingularexplanationsandthatsuchtreatmentinisolationproducesan artificial answer to the key questions surrounding the ongoing armed conflict. To counterbalance the logical fallacies of the current research enterprise, the article advanced the idea of 'sovereign defection' as an altemative explanation. Defining it a breakaway from an existing state, sovereign defection re-framed the issue of causality of the events by usingtheconceptofoutcomeas an analyticaltool. It proposed two categories of sovereigndefection, inwardand outward, and to assess theirempiricalrelevance, thearticleanalysedthedifferenceindynamics of violenceinbothregions:Crimeaand theSouthEast. By underlining the role of non-state actors as remarkably distinct in the two regions, the article put forward the claim that, essentially, the armed conflict in Ukraine portrays a Russiansearchfor interrelated yetdistinctoutcomes:theterritorial seizureand annexation of the CrimeanPeninsula, and the establishment of a political buffer-zone in the shape of a frozenconflictinthe South East. By using a combination of Russian Special Forces and auxiliaries, Russia obtained effective control over the Black Sea Fleet. Similarly, by employing the pro-Russian separatist as proxy forces, Russia pushed forthecreation of a de factorstate, a significantcontrolmechanismalready in practice inregions suchas Transnitriaor SouthOssetia. Thearticle's pursuitsareonlytentativeand, theongoingcharacter oftheconflict diminishesanypredictiveattempts. However, by comparingthepattern of military interventionand by drawinga cleardistinctionbetweenthe uses ofnon-stateactors, thearticlehas pushed the debate towardsnewquestions. Taken seriatim, the most important question the article addressed was that on the sought outcomes of the Russian incursions into Ukrainianterritory. Essentially, this was a twofolddiscussionabout the constructionand directionality of militaryinterventionas a foreignpolicy tool. While retainingthe obvious Clausewitzianundertone linkingwarto politics, itdepartedfrommainstreamconceptualizations ofcauseandrefinedthedebateby shiftingfocuson purpose. Thearticle'sattemptat grasping finernuances of Russianforeign policy added to the dominantnarrative of interestand power a sense of regional historicity, one capable of explaining events in a more comprehensive manner by effectively detaching the analysis from slowly crushing Cold War geopolitical burden. In this way, it echoed the importance of understating Russian attitudes towards Ukraine as "largely consistent with historical Russian (and Soviet) thinking about security interests and foreign policy, not only over the past decade but going back some three centuries' (Oliker et al. 2015, 1).

\section{Notes on contributor}

Vladimir Rauta is a Teaching Fellowin Strategic Studies with PBS@Cranwell and a PhD candidate in the School of Politics and International Relations at the University of Nottingham. He specializes in indirect third party military interventions, respectively, proxy wars and proxy warfare.

\section{Disclosure statement}

No potential conflict of interest was reported by the author.

\section{Notes}

1. Sergey Aksyonov is the current Prime Minister of the Republic of Crimea (Shuster 2014b).

2. Correspondence with the Ukrainian Embassy in London (21 July 2015) emphasizes that use of 'civil war' is a misnomer. Specifically, the argument stresses thatthe ongoingsituationis notan internalconflictand thatUkraine is engagingRussianregulartroops. Similarconcernswere raised in reference to the use of 'rebelgroups'. Itwas noted thatthe Ukrainianauthoritieslabelthepro-Russianseparatistsas 'terrorists'. The articleadmits that'civilwar'carriesastigmaofchaosandloss ofabilityto effectivelycontrol. However, inthelightofthearticleputtingforwardan objective, non- biased argument, as well as for the sake of academic consistency, the concept of 'civil war' will be used. For these purposes, 
Kalvays' definition will be used:'armed conflictwithinthe boundaries of a recognised sovereignentitybetween parties subjectto a common authorityattheoutset of hostilities'(2006,17). Moreover, to accuratelyrepresentthefacts, thearticlerefinestheconceptbyspecificallylabelling it 'internationalisedcivil war'. Thisrepresents an intrastateconflictwithforeigninvolvement. FollowingtheUppsalaConflictDataProgram's definition, thisis'anarmed conflict between a government and a non-government party where the government side, the opposing side, or both sides, receive troop support from other govemments that actively participate in the conflict'(UCDP 2015).

3. The article returns to this point further one in detail. Despite vehement denials on behalf of Russia, conclusive evidence has been presented by the Ukrainian authorities, NATO and independent sources. Communication with the Ukrainian Embassy in London (21 July 2015) acknowledged and stressed thisaspectas a fundamentalfeature of the conflict(Embassy ofUkraineto theUnitedKingdom ofGreatBritainandNorthern Ireland 2015).

4. Putin defended the volunteer thesis and was quoted saying 'We're not attacking anyone' (Greene and Cullinane 2014). Later, Putin stressed similar tone and continued with dismissing claims of Russian troop involvement as 'nonsense' (Demirjian 2015).

5. Theissuesofbiasisa significantone, andinformationfrom organizationssuchas OpenRussiashouldbeapproachedcautiously. However, itis worth underlining that the data are corroborated from two human rights groups, Cargo 200 and the regional societies of soldiers' mothers (Gregory 2015).

6. After being dissolved through Presidential decree on account of force brutality in February 2014, Berkut dismantled and its members have been seen fighting alongside both sides of the conflict (Shelomovskiy 2014)

7. External support has received substantial attention in research. However, in the light of space considerations, the article does not provide a review of the literature, thefocusbeingonitspoliticalconsequencesandtheemergenceof a strategy ofwarby proxy (Bymanetal. 2005; Cunningham 2010; Salehyan, Gleditsch, and Cunningham 2011; Salehyan, Siroky, andWood 2014).

\section{References}

Akinyemi, Aaron. 2014. Ukraine crisis: World leaders react to unfolding disaster in Crimea. International Business Times, March 2. http:/www.ibtimes.co.uk/ukraine-crisis-world-leaders-react-unfolding-crisis-crimea-1438553 ～(accessed July 27, 2015.

Aljazeera. 2015. Fighting flares up in Ukraine amid shaky truce. April 14. http://www.aljazeera.com/news/2015/04/fighting-flares-ukraine-shakytruce-150414184045637.html (accessed July 29, 2015.

Allison, Roy. 2015. Russian 'deniable intervention' in Ukraine: how and why Russia broke the rules. http://uww.chathamhouse.org/publication/russian-

\%E2\%80\%98deniable-intervention\%E2\%80\%99-ukraine-how-and-why-russia-broke-rules\#sthash.0OkFtcoE.dpuf (accessed July 31, 2015.

Babiak, Mat. 2014a. Insurgents identified: The green men of Vkontakte. Ukrainian Policy, April 23. http:/ukrainianpolicy.com/insurgents-identifiedthe-green-men-of-vkontakte/ (accessed July 27, 2015.

Babiak, Mat. 2014b. Welcome to new Russia. Ukrainian Policy, May 23. http://ukrainianpolicy.com/welcome-to-new-russia/ (accessed July 10, 2015). 
Barbashin, Anton, and Hannah Thoburn. 2014. Putin's brain. Foreign Affairs, March 31. https:/www.foreignaffairs.com/articles/russia-fsu/201403-31/putins-brain (accessed July 29, 2015).

Bartles, Charles K., and Roger N. McDermott. 2015. Russia's military operations in Crimea: Road-testing rapid reaction capabilities. Problems of Post-Communism 61: 46-63.

BBC News. 2005. Putin deplores collapse of USSR. April 25. http://news.bbc.co.uk/1/hi/4480745.stm(accessed July 29, 2015).

BBC News. 2014a. Ukraine crisis: UN chief Ban Ki-moon's 'deep concern'. March 20. http://www.bbc.co.uk/news/world-us-canada-26674370 (accessed July 12, 2015).

BBC News. 2014b. Ukraine crisis: Timeline. November 13. http://www.bbc.co.uk/news/world-middle-east-26248275 (accessed July 8, 2015)

Beckhusen, Robert. 2014. How Ukraine's arsenal matches up against the Russian-backed separatists. Reuters, December 2. http://blogs.reuters.com/great-debate/2014/12/02/how-ukraines-arsenal-matches-up-against-the-russian-backed-separatists/） (accessed July 29, 2015).

Bellingcat. 2015. Origin of artillery attacks on Ukrainian military positions in Eastern Ukraine between 14 July 2014 and 8 August 2014 - A Bellingcat investigation. February 17. https:/www.bellingcat.com/wp-content/uploads/2016/02/bellingcat__origin_of_artillery_attacks_02-12-15_final1.pdf (accessed July 29, 2015).

Biersack, John, and Shannon O'Lear. 2015. The geopolitics of Russia's annexation of Crimea: Narratives, identity, silences and energy. Eurasian Geography and Economics 55, no. 3: 247-269.

Bogomolov, Alexander, and Oleksandr Lytynenko. 2012. A ghost in the mirror: Russian soft power in Ukraine. 1 January. https://www.chathamhouse.org/publications/papers/view/181667\#sthash.wGWposJQ.dpuf (accessed July 25, 2015).

Borger, Julian, and Eliot Higggins. 2015. Russia shelled Ukrainians from within its own territory, says study. The Guardian, February 17. http://www.theguardian.com/world/2015/feb/17/russia-shelled-ukrainians-from-within-its-own-territory-says-study (accessed July 29, 2015).

Boulding, Kenneth E. 1962. Conflict and defense: A general theory. New York: Harper.

Bourne, Michael. 2007. Arming Conflict. Basingstoke: Palgrave.

Braithwaite, Roderic. 2014. Russia, Ukraine and the West. The RUSI Journal 159, no. 2: 62-65.

Brun, Brigadier General Itai. 2010. 'While you're busy making other plans' - The 'other RMA'. Journal of Strategic Studies 33: 535-565.

Byman, Daniel, Peter Chalk, Bruce Hoffman, William Rosenau, and David Brannan. 2005. Trends in outside support for insurgent movements. http:/www.rand.org/pubs/monograph_reports/MR1405.html (accessed July 30, 2015).

Byman, Daniel, and Sarah E. Kreps. 2010. Agents of destruction? Applying principal-agent analysis to state-sponsored terrorism. International Studies Perspectives 11, no. 1: 1-18. 
Clem, Ralph. 2014. Dynamics of the Ukrainian state-territory nexus. Eurasian Geography and Economics 55, no. 3: 219-235.

Collier, David, and James E. Mahon Jr. 1993. Conceptual 'stretching' revisited: Adapting categories in comparative analysis. The American Political Science Review 87: 845-855.

Cunningham, David E. 2010. Blocking resolution: How external states can prolong civil wars. Journal of Peace Research 47: 115-127.

Czuperski, Maksymilian, John Herbst, Eliot Higgins, Alina Polyakova, and Damon Wilson. 2015. Hiding in plain sight. Putin's war in Ukraine. Atlantic Council. http://www.attlanticcouncil.org/publications/reports/hiding-in-plain-sight-putin-s-war-in-ukraine-and-boris-nemtsov-s-putin-war (accessed July 21, 2015).

David, Steven. 1997. Internal war: Causes and cures. World Politics 49: 552-576.

Davis, Diane E. 2009. Non-state armed actors, new imagined communities, and shifting patterns of sovereignty and insecurity in the modern world. Contemporary Security Policy 30: 221-245.

Demijian, Karoun. 2015. Putin denies Russian troops are in Ukraine, decrees certain deaths secret. March 28. https:/www.washingtonpost.com/world/putin-denies-russian-troops-are-in-ukraine-decrees-certain-deaths-secret/2015/05/28/9bb15092-0543-11e593f4-\{24d4af7f97d_story.html (accessed July 21, 2015).

Donaldson, Day Blakely. 2014. Putin admits invading Ukrainian Crimea, denies similar invasion of Southeast Ukraine. Guardian Liberty Voice, April 17. http:/guardianlv.com/2014/04/putin-admits-invading-ukrainian-crimea-denies-similar-invasion-of-southeast-ukraine/ (accessed July 21, 2015). Donnelly, Catherine. 2007. Delegation of Governmental Power to Private Parties. Oxford: Oxford University Press.

Embassy of Ukraine to the United Kingdom of Great Britain and Northern Ireland. 2015. Arseniy Yatsenyuk at Chatham House: Putin's fingerprints are onMinskdeal. Heisobligedtofufflit. July 16 . http://uk.mfa.gov.ua/en/press-center/news/38231-arseniy-yatsenyuk-at-chatham-house-putinsfingerprints-are-on-minsk-deal-he-is-obliged-to-fulfil-it (accessed July 27, 2015).

Engle, Eric. 2015. A new cold war? Cold peace. Russia, Ukraine, and NATO. Saint Louis University Law Journal 59: 97-174.

Euromaidan. 2014. 'Men in black', the new defenders of Ukraine, announce mission to liberate Southeastern Ukraine from Russian terrorists. April 28. http://euromaidanpress.com/2014/04/28/black-men-the-new-defenders-of-ukraine-announce-mission-to-liberate-southeastern-ukraine-fromrussian- terrorists/ (accessed July 22, 2015).

European Union External Action Service. 2014. Statement by EU highrepresentative Catherine Ashton on the developments in Ukraine's Crimea. March 1. 140301/01. http://eeas.europa.eu/statements/docs/2014/140301_01_en.pdf(accessed July 27, 2015).

Ferguson, Jonathan, and N. R. Jenzen-Jones. 2014. Raising red flags: An examination of arms \& munitions in the ongoing conflict in Ukraine. Armament Research Senvices (ARES). http://armamentresearch.com/Uploads/Research\%20Report\%20No.\%203\%20\%20Raising\%20Red\%20Flags.pdf (accessed July 29, 2015).

Galeotti, Mark. 2014a. Putting the 'Crime' back in Crimea. The Moscow Times, June 3. http:/hww.themoscowtimes.com/opinion/article/puttingthe- crime-back-in-crimea/501477.html (accessed July 10, 2015). 
Galeotti, Mark. 2014b. Crime and Crimea: Criminals as Allies and Agents. Radio Free Europe - Radio Liberty, November 3. http://www.rferl.org/content/crimea-crime-criminals-as-agents-allies/26671923.html ～(accessed July 10, 2015).

Galeotti, Mark. 2015. Spetsnaz: Russia’s Special Forces. Oxford: Osprey.

Gilardi, Fabrizio. 2008. Delegation in the Regulatory State. Cheltenham: Edward Elgar.

Greene, Richard Allen, and Susannah Cullinane. 2014. Putin: If Russian bear sits still, his teeth, claws will be pulled out. CNN, December 18. http://edition.cnn.com/2014/12/18/world/europe/russia-putin-media-conference/ （accessed July 28, 2015).

Grytsenko, Oksana, and Shaun Walker. 2013. Ukrainians call for Yanukoyych to resign in protests sparked by EU u-turn. The Guardian, December 2. http:/www.theguardian.com/world/2013/dec/01/ukraine-largest-street-protests-orange-revolution (accessed July 21, 2015).

Hansen, Femming Splidsboel. 2015. Framing yourselfinto a corner: Russia, Crimea, and the minimal action space. European Security 24:141158. Heinsch, Robert. 2015. Conflict classification in Ukraine:The return of the 'proxy war'? International Law Studies 91:323-360.

Hughes, Geraint. 2012. My enemy's enemy. Proxy warfare in international politics. Eastbourne: Sussex Academic Press. International Institute for Strategic Studies. 2015. Russia's motives in Ukraine. Strategic Comments 20 (4): viii-ix. Jackson, Thomas. 2010. From under their noses: Rebel groups' arms acquisition and the importance of leakages from state stockpiles. International Studies Perspectives 11: 131-147.

Jentzsch, Corinna, Stathis N. Kalyvas, and Livia Isabella Schubiger, eds. 2015. Militias in civil wars. Journal of Conflict Resolution 59: 755-769. Johnson, Dave. 2015. Russia's approach to conflict- Implications for NATO's deterrence and defence. NATO Research Papers. http://www.ndc.nato.int/news/current_news.php?icode=797 (accessed July 22, 2015).

Jonsson, Oscar, and Robert Seely. 2015. Russian full-spectrum conflict: An appraisal after Ukraine. The Journal of Slavic Military Studies 28: $1-22$.

Josselin, Daphne, and William Wallace, eds. 2003. Non-State Actors in World Politics. London: Palgrave. Kalyvas, Stathis. 2006. The Logic of Violence in Civil War. Cambridge: Cambridge University Press.

Kalyvas, Stathis. 2008. Ethnic defection in civil war. Comparative Political Studies 41: 1043-1068.

Karagiannis, Emmanuel. 2014. The Russian interventions in South Ossetia and Crimea compared: Military performance, legitimacy and goals. Contemporary Security Policy 35: 400-420.

Karber, Phillip. 2015. Russia's 'new generation warfare'. April 6. https:/www.nga.mil/MediaRoom/News/Pages/Russia's-New-GenerationWarfare'.aspx (accessed July 25 2015).

Kemp, Walter. 2004. The business of ethnic conflict. Security Dialogue 35, no. 1: 43-59. 
Kipp, Jacob. 2012. Russian sixth generation warfare and recent developments. Eurasia Daily Monitor 25 January.

http://www.jamestown.org/programs/edm/single/?tx_ttnews\%5Btt_news\%5D=38926\&cHash=2da97e307823618aa

7c45191ac729ddf\#.VsID6bJ4bIU (Accessed July 29, 2015)

Kozlowska, Hannah. 2015. The Fascists are coming. June 2. http://foreignpolicy.com/2014/06/02/the-fascists-are-coming-the-fascists-are-coming/ (accessed July 23, 2015)..

Kramer,AndrewE., andMichaelR. Gordon.2014. Russiasenttanksto separatistsinUkraine,U.S. says. TheNew York Times, June13. http://www.nytimes.com/2014/06/14/world/europe/ukraine-claims-full-control-of-port-city-of-mariupol.html?_r=0～(accessed July 12, 2015).

Kramer, A. E., and Andrew Higgins. 2014. Ukraine's forces escalate attacks against protesters. The New York Times, February 20. http://www.nytimes.com/2014/02/21/world/europe/ukraine.html (accessed July 21, 2015).

Krasner, Stephen. 1999. Sovereignty. Princeton: Princeton University Press:.

Krause, Kieth, and Jennifer Milliken. 2009. Introduction: The challenge of non-state armed groups. Contemporary Security Policy 30: 202-220.

Kunitsyn, Serhiy. 2014. Interview with Bohdan Butkevych, The Ukrainian Week (International Edition), April 23.

http://ukrainianweek.com/Politics/108310 (accessed July 21 2015).

Lessing, Benjamin. 2015. Logics of violence in criminal war. Journal of Conflict Resolution.

http://jcr.sagepub.com/content/early/2015/06/03/0022002715587100.abstract (accessed July 21, 2015).

Lipsky, Andrei. 2014. Чудеса в Крыму [Miracles in Crimea]. Novaya Gazeta, July3. http:/www.novayagazeta.ru/politics/62614.html (accessed July 21, 2015).

Lombardi, Ben. 2001. Ukrainian armed forces: Defence expenditure and militany reform. The Journal of Slavic Military Studies 14: 31-68.

Losiev, Ihor. 2014. Crimean Mafia in politics. The Ukrainian Week (International Edition), April 23. http:/ukrainianweek.com/Politics/108311 (accessed July 10, 2015).

Luhn, Alex. 2014. Who are the men rolling into eastern Ukraine in armoured vehicles? The Guardian, April 16.

http:/www.theguardian.com/world/2014/apr/16/who-are-men-eastem-ukraine-tanks ～(accessed July 21, 2015).

Luhn, Alex. 2015. Vladimir Putin declares all Russian military deaths state secrets. The Guardian, May 28.

http:/www.theguardian.com/world/2015/may/28/vladimir-putin-declares-all-russian-military-deaths-state-secrets (accessed July 29, 2015).

MacFarquahar, Neil. 2015. Putin contradicts Claims on annexation of Crimea. The New Your Times, March 9.

http:/www.nytimes.com/2015/03/10/world/europe/putin-contrary-to-earlier-assertions-suggests-planning-to-seize-crimea-started-in-early-2014.html?_r=0 (accessed July 10, 2015).

Malet, David. 2013. Foreign Fighters. Oxford: Oxford University Press.

Marsh, Nicholas. 2007. Conflict specific capital: The role of weapons acquisition in civil war. International Studies Perspectives 8: 54-72.

McFaul, Michael, Stephen Sestanovich, and John J. Mearsheimer. 2014. Faulty powers who started the Ukraine crisis?. Foreign Affairs. 
Mills, Laura, and Vladimir Isachenkov. 2014. 'Crimea is ours, and that's that': Russia pulls back a battalion from Ukraine border. The Associated Press (National Post), March 31. http://news.nationalpost.com/news/crimea-is-ours-and-thats-that-russia-pulls-back-a-battalion-from-ukraineborder (accessed July 27, 2015).

Ministry of Defence of Ukraine. 2014a. Defence Minister of Ukraine holds talks with OSCE delegation. October 7. http://www.mil.gov.ua/en/news/2014/10/07/defense-minister-of-ukraine-holds-talks-with-osce-delegation/ (accessed July 29, 2015).

Ministry of Defence of Ukraine. 2014b. Ukrainian people and Armed Forces should be a united body. We'll be unconquerable. http:/www.mil.gov.ua/en/news/2014/10/08/minister-of-defense-\%E2\%80\%98ukrainian-people-and-armed-forces-should-be-a-united-body-well-beunconquerable/ (accessed July 29, 2015).

Ministry of Foreign Affairs of Ukraine. 2014. @MFA_Ukraine. August27. https:/twitter.com/MFA_Ukraine/media (accessed July 28, 2015.

Mumford, Andrew. 2013. Proxy Warfare. Cambridge: Polity.

NATO. 2014. New satellite imagery exposes Russian combat troops inside Ukraine. August 28. http:/aco.nato.int/new-satellite-imagery-exposesrussian-combat-troops-inside-ukraine.aspx (accessed July 29, 2015).

Nilsson, Rasmus. 2013. Russian policy concerming the Black Sea Fleet and its being based in Ukraine, 2008-2010: Three interpretations. Europe-Asia Studies 65, no. 6: 1154-1170.

Novorussia.su. 2014. ДНР и ЛНР приступили к созданию Армии Новороссии [DNR and LC began to create an army of New Russia]. September 16 . http://novorossia.su/ru/node/6688 (accessed July 10, 2015).

Officeforthe Coordination of HumanitarianAffairs. 2015. UKRAINE situation update no. 5 as of 26 June 2015. httpJ//reliefweb.int/sites/reliefweb.intfiles/resources/ocha_ukraine_situation_update_13_-_26_june_2015.pdf (accessed July 10, 2015).

Oliker, Olga, Christopher S. Chivis, Keith Crane, Olesya Tkacheva, and Scott Boston. 2015. Russian foreign policy in historical and current context. Santa Monica, CA: RAND Corporation. http://www.rand.org/pubs/perspectives/PE144.html (accessed July 10, 2015).

Open Russia. 2015. Откуда родом россияне, погибшие в бояхна территории Украины [How come the Russians who died in the fightingon the territory of Ukraine]. January 16. https://openrussia.org/post/view/1931/ (accessed July 29, 2015).

Ostrovsky, Simon. 2015. Russiadenies thatits soldiers are inUkraine, butwetracked one there usinghisselfies. June 16. https://news.vice.com/article/russia-denies-that-its-soldiers-are-in-ukraine-but-we-tracked-one-there-using-his-selfies (accessed July 25, 2015).

Parchomenko, Walter. 2002. Prospects for genuine Reformin Ukraine's security forces. Armed Forced \& Society 28: 279-308.

Pearlman, Wendy, and Kathleen Gallagher Cunningham. 2012. Nonstate actors, fragmentation, and conflict processes. Journal of Conflict Resolution 56: 3-15.

Pegg, Scott. 1998. De Facto states in the international system. Institute of International Relations. The University of British Columbia. Working Paper. No. 21 
Poroshenko, Petro. 2015. President's annual message to Verkhovna Rada of Ukraine 'On the internal and external situation of Ukraine in 2015'. June 4. http://www.president.gov.ua/en/news/shorichne-poslannya-prezidenta-ukrayini-do-verhovnoyi-radi-u-35412 (accessed July 29, 2015).

Recknagel, Charles. 2014. Explainer: How do Russia's and Ukraine's armies compare?. Radio Free Europe - Radio Liberty, March 6. http://www.rferl.org/content/russia-ukraine-armies-compare/25287910.html ～(accessed July 29, 2015)

Reisinger, Heidi, and Aleksandr Golts. 2014. Russia's hybrid warfare - Waging war below the radar of traditional collective defence. NATO Research Papers. http://www.ndc.nato.int/research/research.php?icode=0 (accessed July 22, 2015).

Rogozin, Dmitry. 2014. @Rogozin. July 15. https:/twitter.com/Rogozin/media (accessed July 27, 2015).

Rojanki, Matt, and Michael Kofman. 2015. A closer look at Russia's 'hybrid war'. Kennan Cable (Wilson Centre). http://www.wilsoncenter.org/sites/defaultfiles/7-KENNAN\%20CABLE-ROJANSKY\%20KOFMAN.pdf （accessed July 22, 2015).

Rosenau, James N. 1980. The Scientific Study of Foreign Policy. London: Frances Pinter.

Rosenau, James N., and Mary Durfee. 1999. Thinking Theory Thoroughly: Coherent Approaches to an Incoherent World. London: Perseus.

Roslycky, Lada. 2011. Russia's smart power in Crimea: sowing the seeds of trust. Southeast European and Black Sea Studies 11, no. 3:299316. Salehyan, Idean. 2010. The delegation of war to rebel organizations. Journal of Conflict Resolution 54:493-515.

Salehyan, Idean, Kristian Skrede Gleditsch, and David E. Cunningham. 2011. Explaining external support for insurgent groups. International Organization 65: 709-744.

Salehyan, Idean, David Siroky, and Reed M. Wood. 2014. External rebel sponsorship and civilian abuse: A principal-agent analysis of wartime atrocities. International Organization 68: 633-661.

Sanders, Deborah. 2008. Ukraine's military reform: Building a paradigm army. The Journal of Slavic Military Studies 21: 599 614.

Sartori, Giovani. 1970. Concept misformation in comparative politics. The American Political Science Review64: 1033-1053. Scheipers, Sibylle. 2015. Unlawful Combatants. Oxford: Oxford University Press.

Semenchenk, Semen. 2014. Interview with Bohdan Butkevych. The Ukrainian Week (International Edition), June 11. http:/ukrainianweek.com/Society/115461 (accessed July 22, 2015)

Shalal, Andrea. 2015. U.S. Air Force leader sees Russia as 'biggest threat'. Reuters, July 8. http://www.reuters.com/article/2015/07/08/us-usarussia- airforce-idUSKCNOPI2VE20150708 (accessed July 29, 2015).

Shellman, Stephen, Clare Hatfield, and Maggie J. Mills. 2010. Disaggregating actors in intranational conflict. Journal of Peace Research 47: 8390.

Shelomovskiy, Petr. 2014. Berkut and Ukrainian soldiers fight pro-Russians near Slovyansk. Demotix, May 31 .

http://www.demotix.com/news/4890666/berkut-and-ukrainian-soldiers-fight-pro-russians-near-slovyansk/all-media (accessed July 29, 2015). 
Shevchenko, Vitaly. 2014. 'Little green men' or 'Russian invaders'? BBC News, March 11. http://www.bbc.co.uk/news/world-europe-26532154 (accessed July 21, 2015).

Shlapentokh, Dmitry. 2014. Implementation of an ideological paradigm: Early Duginian eurasianismand Russia's post-Crimean discourse. Contemporary Security Policy 35, no. 3: 380-399.

Shuster, Simon. 2014a. Ukraine troops in Crimea face dilemma: To defect, flee or fight. Times, March 9. http./time.com/17356/ukraine-troops-incrimea-face-dilemma-to-defect-flee-or-fight/ (accessed July 29, 2015).

Shuster, Simon. 2014b. Putin's man in Crimea is Ukraine's worst nightmare. Time, March 10. http://time.com/19097/putin-crimea-russia-ukraineaksyonov/ (accessed July 21, 2015).

Sinovets, Polina, and Bettina Renz. 2015. Russia's 2014 Military Doctrine and beyond: threat perceptions, capabilities and ambitions. NATO Research Papers. http://www.ndc.nato.int/download/downloads.php?icode=457 (accessed July 22, 2015).

Snegovaya, Maria. 2015. Putin's information warfare in Ukraine. Soviet origins of Russia's hybrid warfare. Institute for the Study of War. http:/understandingwar.org/reportputins-information-warfare-ukraine-soviet-origins-russias-hybrid-warfare ～(accessed July 24, 2015).

Stallard, Katie. 2015. Russian soldiers' deaths raise Ukraine questions. June 10. http://news.sky.com/story/1499223/russian-soldiers-deathsraise- ukraine-questions (accessed July 23, 2015).

Sutyagin, Igor. 2015. Russian Forces in Ukraine. RUSI.

https:/wwww.rusi.org/downloads/assets/201503_BP_Russian_Forces_in_Ukraine_FINAL.pdf (accessed July 27, 2015).

TASS. 2014. Putin signs laws on reunification of Republic of Crimea and Sevastopol with Russia. March 21. http:/tass.ru/en/russia/724785 (accessed July 21, 2015).

The Washington Post. 2014. Transcript: Putin defends Russian interventionin Ukraine. March4. https:/www.washingtonpost.com/world/transcriptputin-defends-russian-intervention-in-ukraine/2014/03/04/9cadcd1a-a3a9-11e3-a5fa-55f0c77bf39c_story.html～(accessed July 29, 2015).

Hegghammer, Thomas. 2013. Should I stay or should I go? Explaining variation in Western Jihadists' choice between domestic and foreign fighting. American Political Science Review 107: 1-15.

Thomas, Timothy. 2015. Russia's military strategy and Ukraine: Indirect, asymmetric - and Putin-led. The Journal of Slavic Military Studies 28: 445-461.

Thornton, Rob. 2015. The changing nature of modern warfare. The RUSI Journal 160, no. 4: 40-48.

Tsygankov, Andrei. 2015. Vladimir Putin's last stand: the sources of Russia's Ukraine policy. Post-Soviet Affairs 31: 279-303.

Tudoroiu, Theodor. 2012. The European Union, Russia, and the future of the transnistrian frozen conflict. East European Politics and Societies 26, no. 1: 135-161. 
Vasylenko, Volodymyr. 2014. Interview by Roman Malko. The Ukrainian Week (International Edition). April 16.

http://ukrainianweek.com/Politics/107813 (accessed July 29, 2015).

Vinci, Anthony. 2008. Anarchy, failed states, and armed groups: Reconsidering conventional analysis. International Studies Quarterly 52: 295314.

Vlasova, Anastasia, and Christopher J. Miller. 2014. Russian soldiers besiege Ukrainian military base near Simferopol. KyivPost, 3 March. http:/www.kyivpost.com/multimedia/photo/russian-soldiers-besiege-ukrainian-military-base-near-simferopol-338231.html (accessed July 22, 2015).

Wilson, Steve, Peter Foster, and Katie Grant. 2014. Ukraine as it happened: Urgent calls for calmas West faces biggest confrontation with Russia since Cold War. The Telegraph, March 2. http://www.telegraph.co.uk/news/worldnews/europe/ukraine/10670827/Ukraine-live-Crimealeader-appeals-to- Putin-to-help-as-Obama-warns-of-costs-to-Moscow.html (accessed July 27, 2015).

Zeitzoff, Thomas, John Kelly, and Gilad Lotan. 2015. Using social media to measure foreign policy dynamics: Anempiricalanalysis of the IranianIsraeli confrontation (2012-13). Journal of Peace Research 52:368-383. 